\title{
DETERMINATION OF ACETONE IN COW'S RAW MILK BY FLOW INJECTION AND GAS CHROMATOGRAPHIC METHODS
}

\author{
O. BATICZ, ${ }^{\mathrm{a}}$ L. VIDA ${ }^{\mathrm{b}}$ and S. TÖMÖSKÖZI ${ }^{\mathrm{a} *}$ \\ ${ }^{a}$ Department of Biochemistry and Food Technology, Budapest University of Technology and Economics, \\ H-1111 Budapest, Müegyetem rkp. 3. Hungary \\ ${ }^{\mathrm{b}}$ Department of Chemical Technology, Budapest University of Technology and Economics, \\ H-1111 Budapest, Budafoki út 8. Hungary
}

(Received: 15 September 2000; accepted: 22 March 2001)

An automatic flow injection (FIA) and two possible reference gas chromatographic (liquid and headspace sampling GC) methods including appropriate sample preparation were developed and validated for determination of acetone in milk. The methods were tested by preserved raw milk samples.

The FIA results were compared with data obtained by GC determinations. It was found that FIA procedure is suitable for rapid automated measurement of acetone in the range of $0-5 \mathrm{mmol}^{-1}$ in milk, therefore it is a promising analytical method for ketosis monitoring in dairy farms.

Keywords: acetone, flow injection analysis, gas chromatography, ketone bodies

Ketone bodies are formed mainly in the liver from acetyl-CoA in mammals. Acetone and acetoacetic acid may be clinically termed as oxidised, isopropanol and $\beta$ hydroxybutyric acid, respectively, and consequently named as reduced ketone bodies. In late pregnancy and early lactation in ruminants, the synthesis of ketone bodies - as important regulating agents of energy metabolism - can be regarded as a physiological process (FEKETE et al., 1999). However, an inadequate diet or different diseases (i.e. metritis, cystic ovarium disease, etc.) cause ketosis, which means an increasing level of ketone bodies in body fluids i.e. blood, urine or milk. Ketosis has been associated with decreased milk yield, increased risk of clinical ketosis and impaired reproductive performance, while clinical ketosis is accompanied by clinical changes such as anaemia, depression or excitation (JORRITSMA et al., 1998).

\footnotetext{
* To whom correspondence should be addressed.

E-mail: tomoskozi.bet@chem.bme.hu;

Fax: (36-1) 463-38-55.
} 
The early detection of disorders, i.e. elevated levels of ketone bodies mainly under subclinical conditions, may reduce the frequency of ketosis - consequently the profit loss in milk production.

Nowadays, in clinical practice acetoacetic acid and $\beta$-hydroxybutyric acid content in body fluids are used to diagnose ketosis. In case of subclinical stage, one of the silent signals is the elevated level of acetone in blood, urine and finally in milk.

Analysis of blood and urine requires more sample preparation and special knowledge, while the determination of acetone in raw milk seems to be a quick and a very useful tool in early detection of this illness (TYÖPPÖNEN \& KAUPPINEN, 1980; VON DIEKMANN et al., 1986).

Ketone bodies in blood and other tissues are usually analysed by chemical, chromatographic, enzymatic and fluorimetric methods. Several chemical methods have been developed for determination of acetone, acetoacetate, $\beta$-hydroxybutyrate, and the total amount of ketone bodies (THIN \& ROBERTSON, 1952; STEGER \& VOIGT, 1970). These methods are based on oxidation of different ketone bodies to acetone and on the determination of acetone by various colorimetric reactions. These methods are quite annoying and time-consuming, especially if one has to deal with samples containing very small amount of ketone bodies and often has to apply hazardous reagents. Furthermore, the common problems in field studies are the chemical instability of acetoacetate in fluids, the matrix interferences and the low recoveries, especially for $\beta$ hydroxybutyrate (64-86\%) (THIN \& ROBERTSON, 1952). The enzymatic and the fluorimetric procedures are based on enzymatic reactions. Enzymatic kits for determination of $\beta$-hydroxybutyrate and acetoacetate are available and are used in human and veterinary clinical practice (WILLIAMSON et al., 1962; DARGEL, 1987; OZAND et al., 1985). These are more specific and rapid methods than the colorimetric methods available, but the sensitivity is the same. Fluorometric methods, based also on enzymatic reaction and fluorescence change of $\mathrm{NADH}$, make it possible to detect very low concentrations of $\beta$-hydroxybutyrate and acetoacetate $\left(<0.1 \mathrm{mmol}^{-1}\right.$ ) (YounG \& RENOLD, 1966).

In order to build up an everyday monitoring system for the cow's populations we have studied the possible ways of automation and cost reduction of acetone determinations in milk. Comparing the methods published in literature, we decided to apply flow injection analysis technique coupled with gas diffusion technique (VoN DIEKMANN et al., 1986; TÖMÖSKÖZI et al., 1999) for raw milk samples.

Nowadays, there are no officially recommended or reference methods in the area of dairy analyses. The use of chromatographic methods, especially headspace gas chromatography (HRADECKÝ et al., 1978; VAN STEKELENBURG \& DE BRUYN, 1970; ERIKSSON, 1972; LÓPEZ-SORIANO \& ARGILÉS, 1985; KIMURA et al., 1985; SIEGEL et al., 
1977; WINTERBACH \& APPS, 1991) can solve most of difficulties of methods mentioned above.

In this paper, we report two possible GC methods to use for reference analysis of acetone.

\section{Materials and methods}

\subsection{Materials}

The methylethylketone reference substance for gas chromatography and the acetone were purchased from Merck, Germany (catalogue numbers: 109709 and 100020). Ethanol was obtained from Reanal Ltd., (catalogue number: 05031-6-69). All other chemicals were of analytical grade obtained from Reanal Ltd., Hungary.

Samples were preserved (with Broad Spectrum Multitabs II from D\&F Control Systems Inc., USA), and raw milk samples were obtained from Hungarian Herd Recording Ltd., Gödöllõ, Hungary.

\subsection{Methods}

1.2.1. Sample preparations. Sample preparation method for FIA assay. Only homogenisation as sample pre-treatment was used for FIA procedure.

1.2.2. Sample preparation method for liquid phase sampling GC assay. Four $\mathrm{ml}$ of milk sample and $0.4 \mu \mathrm{l}$ of ethanol (internal standard) were pipetted into a 10-ml centrifuge tube. Two hundred $\mu \mathrm{l}$ of $3 \mathrm{~mol} \mathrm{l}^{-1}$ freshly prepared TCA (trichloracetic acid) solution was added to the mixture. It has been shaken by hand for $1 \mathrm{~min}$, than has been centrifuged at $7000 / \mathrm{min}(2200 \mathrm{~g})$ for $20 \mathrm{~min}$. The supernatant was passed through a $45 \mu \mathrm{m}$ filter (cat. number: HVLP02500, Millipore Ltd., Ireland) and $2 \mu \mathrm{l}$ of the filtrate was injected directly by syringe into the gas chromatograph.

1.2.3. Sample preparation method for headspace sampling GC assay. Ten $\mathrm{ml}$ of raw milk sample and $1 \mu \mathrm{l}$ of methylethylketone (internal standard) were pipetted into a $20 \mathrm{ml}$ bottle, capped with rubber septum and adjusted to $60{ }^{\circ} \mathrm{C}$ in the air thermostat. A sampling device with a loop volume of $3 \mathrm{ml}$ (Fig. 1) injected the samples.

1.2.4. Preparation of standard solutions. For FIA and gas chromatographic determinations $10 \mathrm{mmol}^{-1}$ acetone stock solution was prepared and diluted in the range of 0.05 to $5 \mathrm{mmol} \mathrm{l}^{-1}$. For GC assays, the acetone standard solution contained the needed amount of internal standards $(0.1 \mu \mathrm{l}$ methylethylketone and ethanol per $\mathrm{ml}$ sample). 


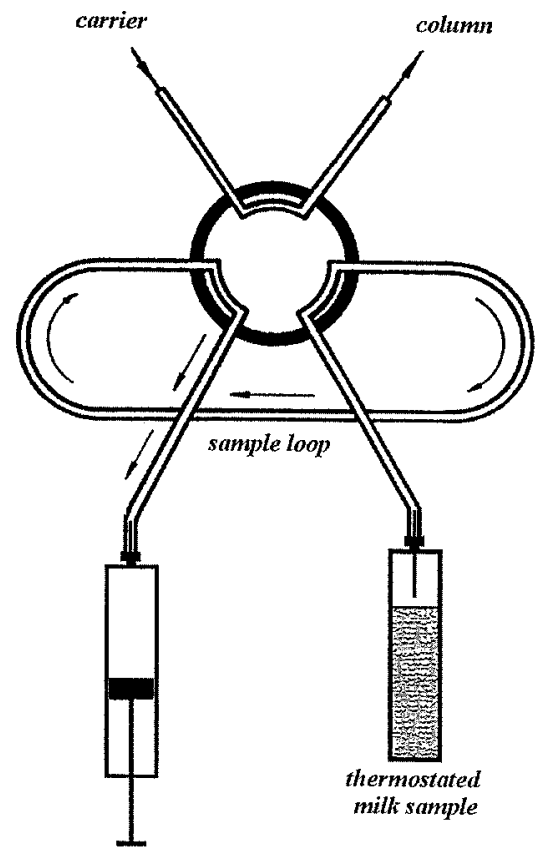

Fig. 1. Sampling device for reduced pressure headspace sampling GC determination of acetone in raw milk

1.2.5. FIA method. The developed method is based on the relatively high volatility of the acetone content of the injected milk sample into the carrier solution, and it can be put through on the gas diffusion membrane and appears in the reagent stream containing indicator and hydroxylamine. The acetone and hydroxylamine react to form acetoxyme. The $\mathrm{pH}$ change during the chemical reaction is detected photometrically. According to the principle of FIA method (VON DIEKMANN et al., 1986), a standard flow injection system (Enviroflow 5012 System and Detector System 5042 made by Foss-Tecator, Sweden) with gas diffusion unit (Chemifold V XS, Foss-Tecator, Sweden) and thermostat (FIAstar 5101, Foss-Tecator, Sweden) was applied. The optimised FIA settings are shown in Fig. 2.

1.2.6. Liquid phase sampling GC method. The developed GC methods were used with the same adsorption chromatographic system: Carlo Erba Vega Series 2 (Carlo Erba, Germany) gas chromatograph model with $6 \mathrm{ft}$. column, packed with Porapack Q 80/100 mesh (from Waters Ltd., USA) and equipped with flame ionisation detector (Carlo Erba, Germany) was used in our experiments. Data were collected with HP 35900 ADC interface and were analysed by HP ChemStation software (Hewlett Packard Ltd., USA). 


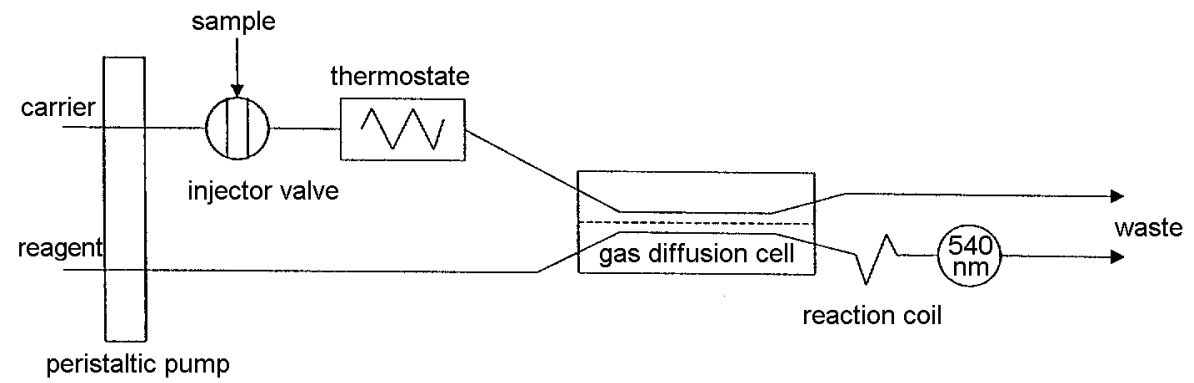

Fig. 2. FIA system for determination of acetone in raw milk. Sample volume: $200 \mu$; Carrier: $2 \mathrm{ml} \mathrm{min}^{-1}$, phosphate buffer $\left(0.1 \mathrm{~mol} \mathrm{l}^{-1}, \mathrm{pH}=7\right)$ containing $1.2 \mathrm{~g} 30 \%$ Brij 35 ; Reagent: $1.5 \mathrm{ml} \mathrm{min}^{-1}, 100 \mathrm{ml}$ methylorange indicator stock solution $\left(0.25 \mathrm{~g} \mathrm{l}^{-1}\right)$ and $150 \mathrm{ml}$ hydroxylamine stock solution $\left(20 \mathrm{~g} \mathrm{l}^{-1}\right)$ were diluted with distilled water to $1000 \mathrm{ml}$; Detection: $540 \mathrm{~nm}$; Cycle time: $80 \mathrm{~s}$; Reaction coil: $0.5 \cdot 60 \mathrm{~cm}$; Thermostat: $80^{\circ} \mathrm{C}$

In order to protect the column from matrix substance contamination in milk samples a precolumn packed with glass wool was inserted in front of the analytical column.

The applied parameters were as follows:

Column:

Column temperature:

Injection:

Injector temperature:

Injected sample volume:

Internal standard:

Detector:

Detector temperature:

Carrier:

Calibration/measurement:
Porapack Q

isotherm, $200{ }^{\circ} \mathrm{C}$

on column

$125^{\circ} \mathrm{C}$

$2 \mu 1$

ethanol

FID

$125^{\circ} \mathrm{C}$

$\mathrm{He}$

The ratio of each peak area to the internal standards was determined and plotted against the concentration ratio. 
1.2.7. Headspace sampling GC method. The headspace-sampling device is shown in Fig. 1. Conditions of the analytical determination were:

Column:

Porapack Q

Column temperature:

isotherm, $175^{\circ} \mathrm{C}$

Sampling:

reduced pressure headspace

Sample loop:

$3 \mathrm{ml}$

Internal standard:

methylethylketone

Detector:

FID

Detector temperature:

$120^{\circ} \mathrm{C}$

Carrier:

$\mathrm{He}$

The developed FIA and GC methods were investigated to establish their performance parameters. The results were analysed by Statistica.5 (StatSoft Ltd., USA) software.

\section{Results}

\subsection{FIA method}

The test range was declared between 1 and $10 \mathrm{mmol}^{-1}$ acetone concentration, according to the physical range of measurable values published in the literature. The calibration was performed using water solutions, because during the pre-examinations significant differences were not found among the results obtained from water and milk standard solutions. The standard curves were linear in the whole concentration range tested. The slope and the intercept of the calibration curve mainly depended on the status of the gas diffusion membrane used, so it was necessary to perform a new calibration process before each batch. The average sensitivity of the FIA method was characterised by the average slope of linear calibration curves: $225.9 \pm 4.74$ absorbance unit per mmol $\mathrm{l}^{-1}$. The statistical analysis of variances of the measured absorbance values of standards showed that the variances were constant at $\alpha=0.05$ significance level. The results of residual analysis and trend-test (no trend, no extreme value, the residuals have normal distribution) also proved the suitability of the calibration method applied.

The detection limit was established on base of average results of blank samples' repeated measurements $\left(0.03 \mathrm{mmol} \mathrm{l}^{-1}\right)$. The reproducibility of FIA method (SD $\%<2.2$ ) was defined by variance analysis. Date, staff and replicates played a role in variance factors. The results are shown in Fig. 3. At a very low concentration - close to the detection limit of the method - there was no effect of different operators, and this might be explained by the uncertainty of the determination itself. At higher concentrations there was not found an effect of different date, and according to the 
raising acetone concentration an increase of the effect of operator and replicates were found. The precision of the FIA assay was determined by recovery percentages of the acetone added to the samples (Table 1). The FIA method is precise enough because of the narrow range of recovery results $(98.8-110.6 \%)$ given. (At the lowest standard concentration the higher than $105 \%$ recovery can be explained by the uncertainty of the acetone addition.) Therefore, it seems to be appropriate for determination of acetone in raw milk samples.

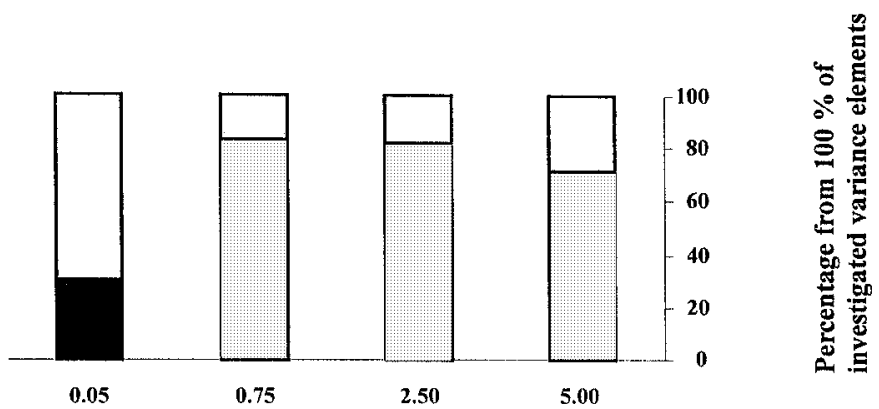

Acetone concentration, $\mathrm{mmol} \mathrm{I}^{-1}$

Fig. 3. The reproducibility of FIA method: the influence of the investigated variance elements. of replicates; $\square$ : effect of operator; $\square$ : effect of date

Table 1

Precision of the FIA assay, determined by recovery percentages of the acetone added to samples

\begin{tabular}{lccc}
\hline Sample id. & $\begin{array}{c}\text { Acetone added } \\
\left(\mathrm{mmol} \mathrm{1}^{-1}\right)\end{array}$ & $\begin{array}{c}\text { Recovery } \\
(\%)\end{array}$ & $\begin{array}{c}\text { SD } \\
(\%)\end{array}$ \\
\hline Milk 1 & 0.05 & 110.6 & 1.90 \\
Milk 2 & 0.10 & 104.7 & 2.03 \\
Milk 3 & 0.50 & 103.6 & 1.12 \\
Milk 4 & 1.00 & 98.8 & 0.97 \\
Milk 5 & 2.50 & 101.5 & 0.69 \\
\hline
\end{tabular}

Results represent 5 independent determinations 

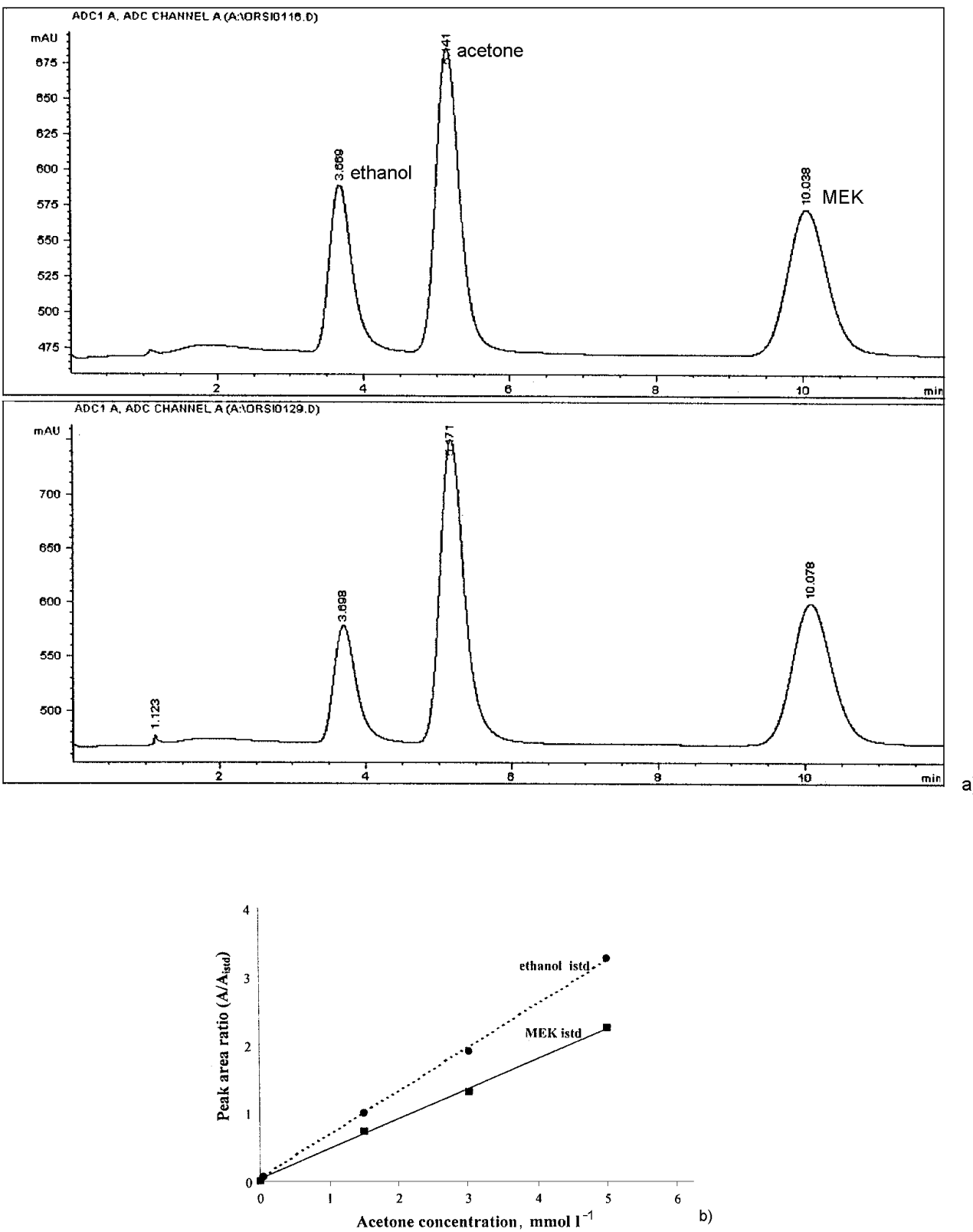

Acta Alimentaria 30, 2001 
$\Leftarrow$ Fig. 4. Headspace chromatograms of $3 \mathrm{mmol}^{-1}$ acetone standard solution, one of the raw milk samples with ethanol and methylethylketone (MEK) internal standards (a), and calibration graphs for headspace sampling GC (b). Calibration with ethanol istd.: $y=0.6503 x, R^{2}=0.9991$; with methylethylketone: $\mathrm{y}=0.4532 \mathrm{x}, \mathrm{R}^{2}=0.9992$

Table 2

Average retention times of the components of interest

\begin{tabular}{lcc}
\hline Component & $\begin{array}{c}\text { Average retention at liquid phase } \\
\text { sampling GC } \\
(\text { min) }\end{array}$ & $\begin{array}{c}\text { Average retention } \\
\text { at headspace sampling GC } \\
(\min )\end{array}$ \\
\hline Ethanol & 1.73 & 3.56 \\
Acetone & 2.47 & 5.14 \\
Methylethylketone & not detectable in preserved raw milk matrix & 10.04 \\
\hline
\end{tabular}

\subsection{GC methods}

During the calibration process, excellent separation of ethanol, acetone and methylethylketone was obtained by the developed and previously described GC methods (Fig. 4). Comparing the separation of two GC methods during the measurements of the milk samples, it was found that the liquid phase sampling GC was not suitable to separate the methylethylketone peak from the matrix peaks clearly. We have decided using ethanol as an internal standard since it has a rather short retention time. The retention times of components of interest are shown in Table 2.

The standard curves for both methods were linear in the whole concentration range tested. They were plotted from water or milk solutions of the standards. Significant differences were not found between calibrations (Fig. 5) and measurement data of milk samples (Table 3). According to these results, the standards were prepared in water solutions. The errors of peak area ratios of headspace sampling GC are shown in Fig. 6. It was found that the deviation of analytical determinations was related to the concentration of the samples analysed. To define the reproducibility of the injection, two different concentration levels of standard solution were injected into a gas chromatograph 5 times. (Results are shown in Table 4). The standard deviations involve the differences related to the manual injection procedures. The precision of methods developed by the authors was determined by recovery percentages of the acetone added to milk samples. The results of headspace sampling process were better than those of liquid phase sampling GC (Table 5). The correlation diagram of FIA and liquid phase sampling GC method in case of 9 different milk samples are shown in Fig. 7. 
Figure 8 display the correlation diagram between FIA and headspace sampling GC method for 20 milk samples analysed. In addition the FIA-results and the two GCresults were compared and analysed by t-test. Significant differences were not found between the result obtained by FIA and headspace sampling GC, but differences were found between FIA and liquid phase sampling GC, however, it must be kept in mind that in second case the number of samples was less.

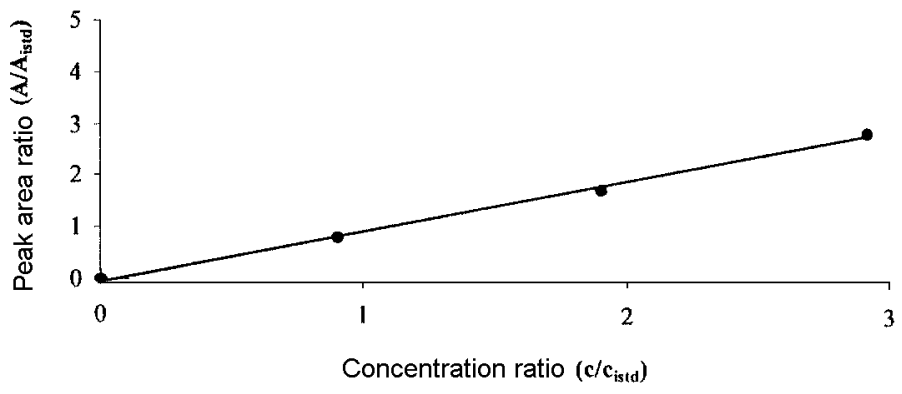

a)

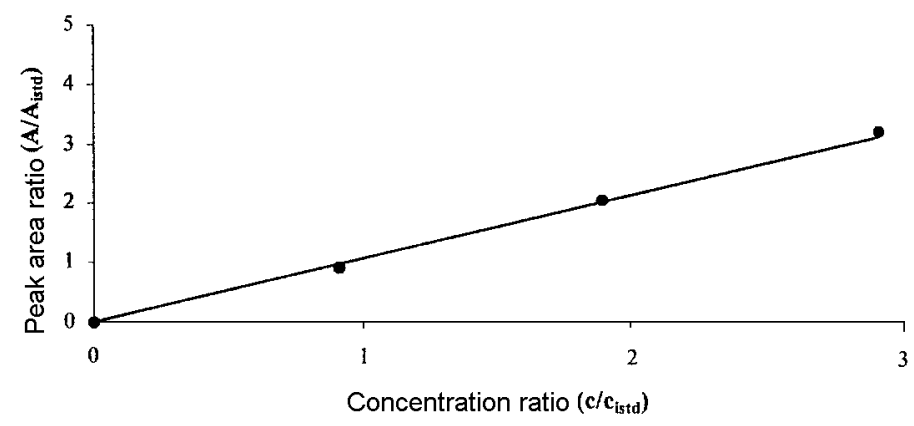

b)

Fig. 5. Plot of calibrations for determination of acetone by liquid phase sampling GC method. Acetone standards were prepared from water standard solutions $\left(\mathrm{y}=0.9978 \mathrm{x}, \mathrm{R}^{2}=0.9982\right)$ (a) and from milk standard solutions $\left(\mathrm{y}=1.0584 \mathrm{x}, \mathrm{R}^{2}=0.9963\right)(\mathrm{b})$ 


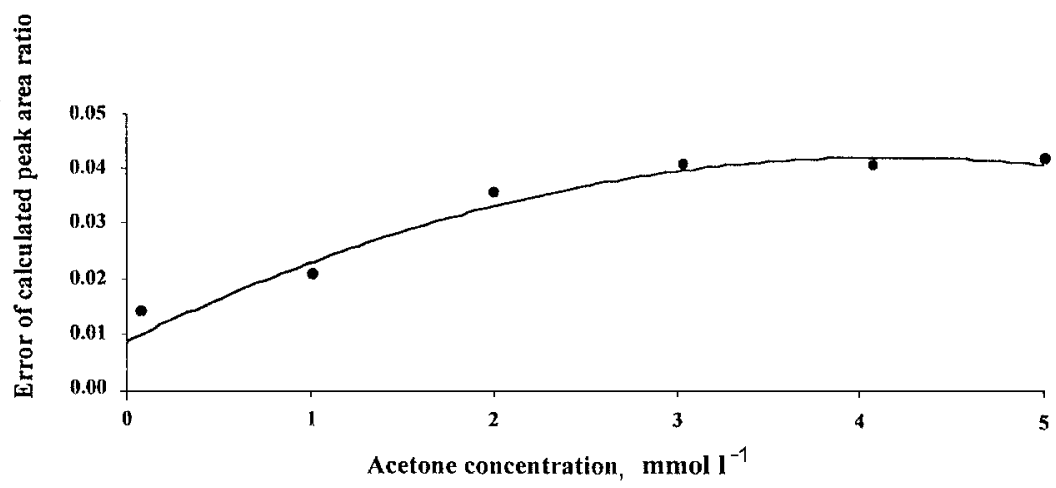

Fig. 6. Relationship between the acetone concentration and the error of analytical determination. Fitted function: $y=-0.0019 x^{2}+0.0162 x+0.0086, R^{2}=0.8799$

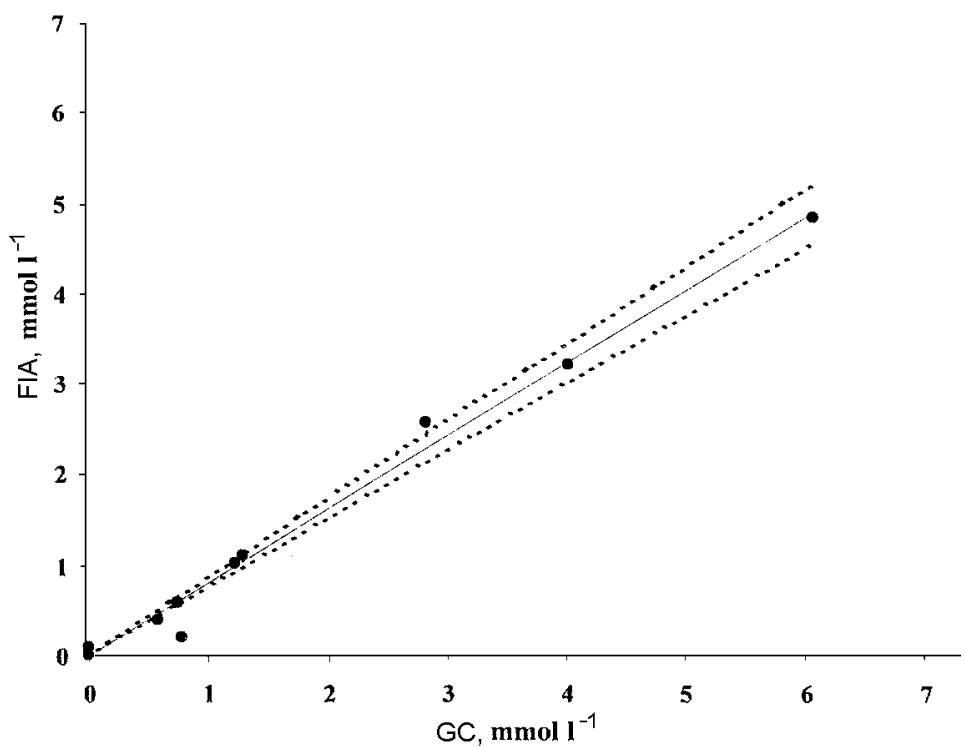

Fig. 7. Correlation between results of FIA and liquid phase sampling GC procedures for 9 milk samples. Fitted function: $y=0.8094 x, R^{2}=0.9877$. Confidence band: $95 \%$ 


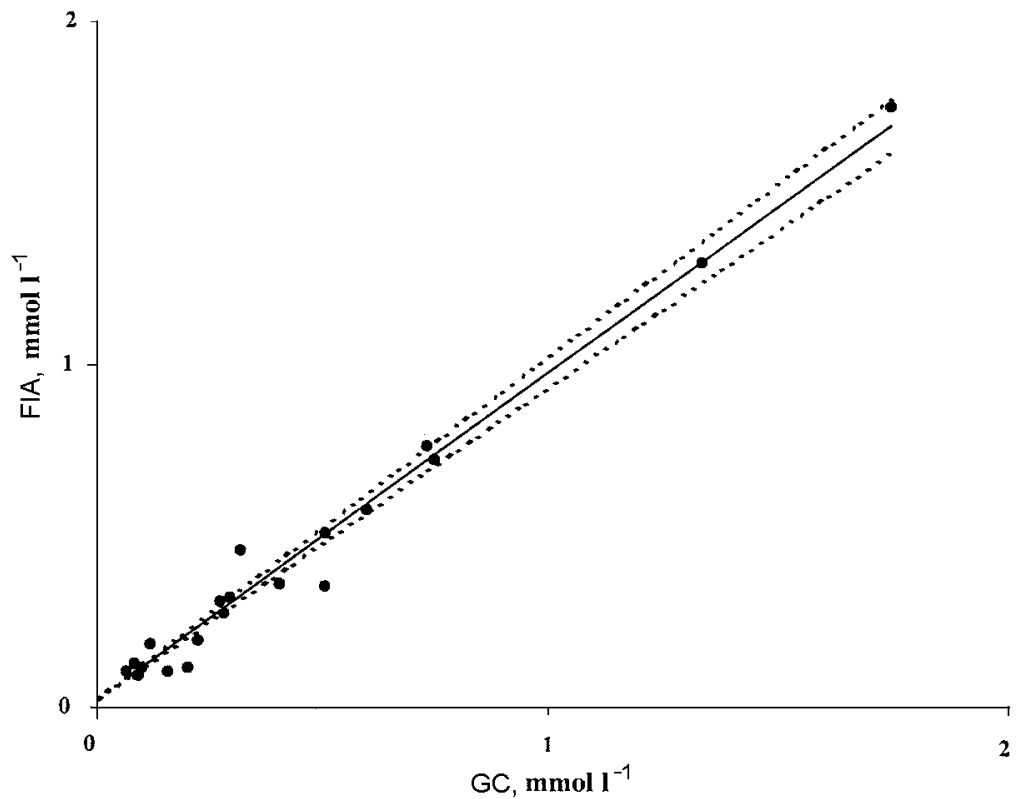

Fig. 8. Correlation between results of FIA and headspace sampling GC procedures for 20 milk samples. Fitted function: $y=0.9893 x, R^{2}=0.9807$. Confidence band: $95 \%$

Table 3

Liquid phase sampling GC measurements of raw milk samples with water and milk calibration standard solutions. The results represent 3 independent sampling

\begin{tabular}{lcccc}
\hline Sample id. & $\begin{array}{c}\text { Average } \\
\left(\mathrm{mmol} \mathrm{l}^{-1}\right)\end{array}$ & $\begin{array}{c}\text { SD } \\
\left(\mathrm{mmol} \mathrm{l}^{-1}\right)\end{array}$ & $\begin{array}{c}\text { Average } \\
\left(\mathrm{mmol} \mathrm{l}^{-1}\right)\end{array}$ & $\begin{array}{c}\text { SD } \\
\left(\mathrm{mmol} \mathrm{l}^{-1}\right)\end{array}$ \\
\hline Milk 1 & 3.68 & 0.052 & 4.03 & 0.057 \\
Milk 2 & 5.56 & 0.839 & 6.08 & 0.918 \\
Milk 3 & 0.53 & 0.065 & 0.58 & 0.071 \\
Milk 4 & 4.26 & 0.856 & 4.66 & 0.935 \\
Milk 5 & 2.59 & 0.057 & 2.83 & 0.063 \\
Milk 6 & 1.11 & 0.216 & 1.22 & 0.236 \\
\hline & (milk calibration standards) & (water calibration standards) \\
\hline
\end{tabular}


Table 4

Results of the investigation of injection procedures

\begin{tabular}{|c|c|c|c|c|c|c|c|}
\hline Sample & $\mathrm{A} / \mathrm{A}_{\text {istd }}$ & Average & SD & Sample & $\mathrm{A} / \mathrm{A}_{\mathrm{istd}}$ & Average & SD \\
\hline \multirow[t]{5}{*}{$0.10 \mathrm{mmol} \mathrm{l}^{-1} \mathrm{st}}$. & 0.075 & 0.126 & 0.0708 & $0.05 \mathrm{mmol} \mathrm{l}^{-1}$ st. & 0.039 & 0.059 & 0.0141 \\
\hline & 0.116 & & & & 0.059 & & \\
\hline & 0.248 & & & & 0.065 & & \\
\hline & 0.110 & & & & 0.053 & & \\
\hline & 0.079 & & & & 0.077 & & \\
\hline \multirow[t]{5}{*}{$1.00 \mathrm{mmol} \mathrm{l}^{-1} \mathrm{st}}$. & 0.639 & 0.648 & 0.0059 & $0.50 \mathrm{mmol} \mathrm{l}^{-1}$ st. & 0.239 & 0.229 & 0.0177 \\
\hline & 0.651 & & & & 0.245 & & \\
\hline & 0.644 & & & & 0.200 & & \\
\hline & 0.652 & & & & 0.224 & & \\
\hline & 0.652 & & & & 0.235 & & \\
\hline
\end{tabular}

(liquid phase sampling GC method) (headspace sampling GC method)

Table 5

Precision of GC methods. The results represent 5 independent determinations

\begin{tabular}{lcc}
\hline $\begin{array}{l}\text { Acetone } \\
\text { addition }\end{array}$ & $\begin{array}{c}\text { Average recovery } \\
\text { (liquid phase sampling GC method) } \\
(\%)\end{array}$ & $\begin{array}{c}\text { Average recovery } \\
\text { (headspace sampling GC method) } \\
(\%)\end{array}$ \\
\hline $0.25 \mathrm{mmol} \mathrm{l}^{-1}$ & 105.26 & 102.51 \\
$2.50 \mathrm{mmol} \mathrm{l}^{-1}$ & 88.76 & 100.37 \\
$5.00 \mathrm{mmol} \mathrm{l}^{-1}$ & 102.67 & 98.64 \\
\hline
\end{tabular}

\section{Conclusions}

We have launched, optimised and validated a FIA and two possible reference GC methods for the determination of acetone in milk samples. The methods were tested with preserved raw milk samples. The results obtained by optimised FIA method were compared with the results of the headspace and liquid phase sampling GC. We had to take into consideration the results of validation procedure and disadvantages of the liquid phase sampling GC method: it requires too long a time and is very expensive sample preparation method for biological samples such as milk. The advantages of the first are: simple and rapid GC determination can be carried out using by headspace sampling (Table 6). Therefore we suggest using the headspace method as a reference method of acetone determination in raw milk samples in the range of $\mathrm{mmol}^{-1}$ concentrations. 
Table 6

Comparison of the different methods

\begin{tabular}{|c|c|c|c|}
\hline Investigated parameter & FIA & $\begin{array}{l}\text { Liquid phase } \\
\text { sampling GC }\end{array}$ & $\begin{array}{c}\text { Headspace } \\
\text { sampling GC }\end{array}$ \\
\hline - Detection limit $\left(\mathrm{mmol}^{-1}\right)$ & 0.03 & 0.01 & 0.01 \\
\hline - Linear range $\left(\mathrm{mmol} \mathrm{l}^{-1}\right)$ & $0-10$ & $0-10$ & $0-10$ \\
\hline - Calibration requirement & before each batch & only control & only control \\
\hline $\begin{array}{l}\text { - Sensitivity (slope of linear } \\
\text { calibration graph) }\end{array}$ & $\begin{array}{c}225.9 \pm 4.74 \\
\left(\mathrm{Abs} / \mathrm{mmol} \mathrm{1}^{-1}\right)\end{array}$ & $\begin{array}{c}0.998 \\
\text { (peak/conc. ratios) }\end{array}$ & $\begin{array}{c}0.453 \\
\text { (peak ratio/conc.) }\end{array}$ \\
\hline $\begin{aligned} \text { - Error of analytical } \\
\text { determinations (SD \%) }\end{aligned}$ & - & $<1$ & $<1$ \\
\hline - Reproducibility (SD \%) & $<2.2$ & $<2.0$ & $<2.0$ \\
\hline - Accuracy (aver. recovery \%) & 103.8 & 98.9 & 100.5 \\
\hline - Retention time of acetone (min) & - & 2.74 & 5.14 \\
\hline - Sample preparation & minimal & complex & minimal \\
\hline - Time/sample (min) & 1.5 & 180 & 15 \\
\hline - Cost/sample (USD) & 0.2 & 3 & 5 \\
\hline - Correlation with FIA (corr. coeff.) & - & 0.993 & 0.991 \\
\hline
\end{tabular}

From the investigations presented in this paper the final conclusion is: both, either the FIA method developed should be chosen, - because of its high accuracy, precision, sensitivity and reproducibility - or the headspace GC method can be applied for cow's milk-monitoring. The first is faster and more profitable, especially considering costs per test.

The authors wish to express their appreciation to Prof. S. KEMÉNY (Budapest University of Technology and Economics, Department of Chemical Unit Operation) for his instructions in the statistical analysis, to Mrs. K. Gundel, Mr. S. PRÓKAI and Dr. F. KATONA (Hungarian Herd Recording Ltd., Gödöllö) for making raw milk samples available; to Mrs. Á. MisKOLCZI and Miss A. TARKó for their technical assistance (Budapest University of Technology and Economics, Department of Biochemistry and Food Technology). 


\section{References}

DARGEL, D. (1987): Zur enzymatischen Bestimmung von Azetazetat und D-(-)-3-Hydroxybutyrat im Blut und in der Milch von Kühen. Mh. Vet.-Med., 42, 244-247.

ERIKSSON, C. J. P. (1972): Micro method for determination of ketone bodies by head-space gas chromatography. Anal. Biochem., 47, 235-243.

Fenete, S., AndrÁsofszky, E., Lejtényi, GY., KerÉnyi, J. \& Katona, F. (1999): Genetic and herd diagnostic importance of milk ketone measurement - First Hungarian experiences. Proceedings of The 1st Middle-European Buiatrics Congress, Balatonfüred, Hungary, pp. 309-316.

HRADECKÝ, P., JAGOŠ, P. \& JANÁK, J. (1978): Gas chromatographic head-space analysis of clinically interesting ketone bodies. J. Chrom., 146, 327-332.

Jorritsma, R., Baldée, S. J. C., SchukKen, Y. H., Wensing, Th. \& Wentink, G. H. (1998): Evaluation of a milk test for detection of subclinical ketosis, Vet. Quart., 20, 108-110.

Kimura, M., Kobayashi, K., Matsuoka, A., Hayashi, K. \& Kimura, Y. (1985): Head-space gaschromatographic determination of 3-hydroxybutyrate in plasma after enzymic reactions, and the relationship among the three ketone bodies. Clin. Chem., 31, 596-599.

LÓPEZ-SORIANO, F. J. \& ARGiLÉS, J. M. (1985): Simultaneous determination of ketone bodies in biological samples by gas chromatographic headspace analysis. J. chrom. Sci., 23, 120-123.

Ozand, P. T., Hawkins, R. L., Collins Jr., R .M., Tildon, J. T. \& Cornblath, M. (1985): A microautoanalytic procedure developed for the determination of ketone bodies, gluconeogenic amino acids, pyruvate, lactate, and glucose in metabolic studies. Biochem. Med., 14, 170-183.

SiEgel, L., Robin, N. \& McDonaLD, L. J. (1977): New approach to determination of total ketone bodies in serum. Clin. Chem., 23, 46-49.

Steger, H. \& Voigt, J. (1970): Bestimmungen von Ketokörpern in Blut und Milch. Arch. Tierernahrung, 20, 631-639.

THIN, C. \& RoBERTSON, A. (1952): The estimation of acetone bodies. Biochem. J., 51, 218-223.

TÖMÖSKÖZI, S., BATICZ, O., VIDA, L., CSETE, Zs., Gundel, J., KATONA, F. \& PRÓKAI, S. (1999): Indication of energy-imbalance and primary bovine ketosis with determination of oxidized ketone bodies level in raw milk - A Flow Injection Method. Proceedings of the 1st Middle-European Buiatrics Congress, Balatonfüred, Hungary, pp. 316-320.

TYÖPPÖNEN, J. \& KAUPPINEN, K. (1980): The stability and automatic determination of ketone bodies in blood samples taken in field conditions. Acta vet. Scand., 25, 55-61.

VAn StekelenburG, G. J. \& De BRUYn, W. (1970): A simple gas chromatographic determination of acetone and $\beta$-ketobutyric acid in blood serum by means of head space gas sampling. Clin. chim. Acta, 28, 233-237.

Von Diekmann, L., Pabst, K. \& GraVert, H. O. (1986): Routinebestimmungen des Acetons in Mich in der Fliebinjektionanalyse. Kieler milchw. ForschBer., 38, 205-213.

Williamson, D. H., Mellanby, J. \& Krebs, H. A. (1962): Enzymic determination of D(-)- $\beta$ hydroxybutyric acid and acetoacetic acid in blood. Biochem. J., 82, 90-99.

Winterbach, H., E. K. \& APPS, P. J. (1991): A gas-chromatographic headspace method for the determination of acetone in bovine milk, blood and urine. J. vet. Res., 58, 75-79.

YounG, D. A. B. \& RENOLD, A. E. (1966): A fluorimetric procedure for the determination of ketone bodies in very small quantities of blood. Clin. chim. Acta, 13, 791-793. 